\title{
Transatlantica
}

Revue d'études américaines. American Studies Journal

\section{A World of "Slippy Maps": Google Earth, Global Visions, and Topographies of Memory}

\section{Veronica della Dora}

\section{(2) OpenEdition}

1 Journals

\section{Édition électronique}

URL : https://journals.openedition.org/transatlantica/6156

DOI : $10.4000 /$ transatlantica.6156

ISSN : $1765-2766$

Éditeur

Association française d'Etudes Américaines (AFEA)

\section{Référence électronique}

Veronica della Dora, «A World of "Slippy Maps": Google Earth, Global Visions, and Topographies of Memory », Transatlantica [En ligne], 2 | 2012, mis en ligne le 02 mai 2013, consulté le 06 avril 2023. URL : http://journals.openedition.org/transatlantica/6156 ; DOI : https://doi.org/10.4000/ transatlantica.6156

Ce document a été généré automatiquement le 6 avril 2023.

Creative Commons - Attribution - Pas d'Utilisation Commerciale - Pas de Modification 4.0 International - CC BY-NC-ND 4.0

https://creativecommons.org/licenses/by-nc-nd/4.0/ 


\title{
A World of "Slippy Maps": Google Earth, Global Visions, and Topographies of Memory
}

\author{
Veronica della Dora
}

Having found an area of the planet she is interested in exploring, she takes the equivalent

of a 'magic carpet ride' through a 3-D visualization of the terrain. Of course, terrain is only one of the many kinds of data with which

she can interact. Using the system's voice recognition capabilities, she is able to request information on land cover, distribution of plant and animal species, real-time weather, roads, political boundaries, and population. She can also visualize the environmental information that she and other students all over the world have collected as part of the GLOBE project. (Gore,

In a famous speech delivered to the California Science Center in Los Angeles in 1998, former US vice-President Al Gore expressed the need for a "Digital Earth", a "multiresolution, three-dimensional representation of the planet, into which we can embed vast quantities of geo-referenced data" (ibid.). "We possess unprecedented amounts of geographical information", especially satellite imagery, Gore noted. This information, however, simply lay unutilized in what he called "electronic silos of data". Digital Earth would enable to organize this mass of data in an efficient way and, more significantly, to open "the silos" to the public. By allowing viewers to virtually "fly" from space down to ground level through progressively higher resolution data sets (he aimed at a 1sqm definition), Digital Earth would enable the display of information related to a specific location from an infinite number of sources. A revolutionary device for accessing and 
at the same time producing knowledge, the virtual globe would thus find a variety of applications, from science and policy-making to education.

Emblematically, the vice-President asked his audience to imagine a child playing with Digital Earth at a local museum. By physically interacting with the virtual globe as if "taking a magic-carpet ride", the young girl acquires knowledge about her local environment and the world beyond her visual horizon. Her geographical curiosity embodies and ties ideals of education and citizenship. The cartographic medium becomes an instrument for dealing with the environment and with cultural difference -in other words, for helping the little girl "find her place in the world". At the same time, by adding an input to the virtual globe through her own school project, the little girl (and tomorrow's citizen) also contributes to global knowledge.

Gore's speech can be situated within a long history of global utopian visions which reached their momentum in the late nineteenth century and found their most striking expression in a series of geographic (and cartographic) mega-projects. Perhaps even more significantly, it can be also situated at the beginning of a more contemporary history, that of new "participatory" mapping technologies such as Google Earth (GE) and their derivatives (Google Maps and Street View). These mapping technologies have been regarded by various commentators as marking an epistemic break in the history of cartography; a move away from the static map-object towards an ephemeral interactive mapping environment in which the map is constantly redefined, as are traditional divides between map user and map maker, cartographic and noncartographic information, online and offline worlds (Crampton, 2009; Elwood, 2010; Monmonier, 2007).

4 This essay explores the philosophy underpinning GE and related virtual mappings and their impact on our contemporary offline world from a cultural history of cartography perspective. Having traced a genealogy of "virtual globes", it identifies and discusses four main areas of rupture (and continuity) with previous cartographic traditions: 1) telescopic vision, which is the presentation of cartographic information along the illusion of a "naturalistic" scalar continuum (a seemingly uninterrupted movement from a local to a global scale); 2) the democratization of mapping and the transformation of the map user into co-author; 3) georeferencing, and its impact on our experience of the world; and finally, 4) the transformation of the world itself into a map; one in turn accessible and readable through the mediation of the new mapping technologies.

\section{Virtual globes}

Obviously, no one organization in government, industry or academia could undertake such a project. Like the World Wide Web, it would require the grassroots efforts of hundreds of thousands of individuals, companies, university researchers, and government organizations. ... It could also become a "collaboratory"-a laboratory without walls-for research scientists seeking to understand the complex interaction between humanity and our environment. (Gore, 1998)

Mega-projects are often inspired by mega-problems. Cartographic mega-projects make no exception. The agenda informing Gore's Virtual Globe included: conducting virtual diplomacy; fighting crime; preserving biodiversity; predicting climate change; increasing agricultural productivity. Gore's plans might sound grand and utopian, but if we journey a century back in time we find that the ambitions of late nineteenth- 
century geographers were no less immodest. If the end of the twentieth century was marked by growing concerns about a global environmental crisis (at the centre of Gore's preoccupations), ${ }^{1}$ the end of the previous century was marked by geopolitical tensions, and the prospect of European fragmentation that followed the devastating Franco-Prussian War eventually stimulated a counter-movement towards international cooperation (Brockington, 2009). While the emergence of geography as an academic discipline is closely connected to the self-affirmation of European nation-states and played an important role in shaping and naturalizing nationalisms (thus, in a way, encouraging "fragmentation"), it also offered the language to shape counterhegemonic global imaginations and to develop alternative ideals of citizenship (Schmidt, 2010).

6 For Russian anarchist geographer Petr Aleksejevich Kropotkin, the ultimate goal of geography was to teach that "humans are all brothers, regardless of their nationality", a statement echoed by several other academic geographers and high school instructors of the time (Eva and Ferretti, 2010, 144). ${ }^{2}$ Inspired by the same principles, in the introduction to La Nouvelle Géographie universelle, la terre et les hommes (1875-1894), Kropotkin's French colleague and friend Élisée Reclus thus called for the "future collaboration of observers that, from every corner of the world, will come together to write the great book of human knowledge"-what he called a "truly universal geography". Nationalistic and racial hatred led to ignorance and fragmentation, and eventually to war. "While the savages from distant lands appear to our imagination as immaterial ghosts", Reclus (1875) argued, "our neighbours, our rivals in civilization, appear to us ugly and deformed. In order to see their real aspect, it is first necessary to get rid of any prejudice and of any feeling of contempt, of hate, of rage that still divide nations" (http://www.gutenberg.org/files/28370/28370-0.txt). Only a truly "global" participatory geography could dispel the dark clouds of ignorance and prejudice and thus make the world a better place.

7 Attempts to enact such participatory geography can be read in various grand-scale cartographic projects formulated in the following years, including the first "truly international world map" proposed by German geographer Albrecht Penck in 1891. The map, the fruit of the collaboration between 34 different countries, was to be designed at the 1: 1 million scale and based on international cartographic conventions and symbols, but "with place names expressed in the official languages spoken by the populations represented on each sheet" (Heffernan, 2001, 209). ${ }^{3}$

In 1900 Reclus himself proposed another unrealized cartographic mega-project: a 127,5m-diameter globe to be permanently exhibited at the Trocadero and visible from everywhere in Paris. Designed at a 1:100,000 scale, the interior of the monster globe would feature a concave relief representation of the earth surface-the first global relief map to maintain the proportions of mountain heights. A system of elevated platforms and ladders would enable visitors to move to different parts of the globe giving them the impression of flying over its surface, as with Gore's Digital Earth (Rayward, 2008, 113-16). "Geo-referenced" explicatory panels to be constantly updated in light of recent explorations and discoveries would explain physical and human phenomena to visitors, whereas a library would be made available for further in-depth geographical study. Like Digital Earth, Reclus' globe was targeted at "the general public", including school pupils, as well as adults from subaltern social classes (Ferretti, 
2010, 111-12). It was meant to open up the huge "silos of data" accumulated through the geographical explorations of the last decades.

9 Reclus' monster globe, Penck's international map, and Gore's Digital Earth never materialized. The first project never commenced; the second stranded in 1913 with the withdrawal of the US from the initiative, and the last after Gore lost the presidential elections in 2000. Rather than the last of a series of failed utopian projects, however, the vice-president's speech is usually described by commentators as the beginning of contemporary "participatory cartography", and, more specifically, as a "prophecy" of GE and its derivatives. As Jeremy Crampton notes, Gore's vision captured several aspects of these mapping technologies we tend to take for granted today, including geo-referencing (the naturalistic and interactive display of data according to the geographical location to which they refer), the integration of data from different sources, and, no less importantly, free access to the general public (Crampton, 2008 and 2009).

10 Yet, one aspect that makes these interactive maps different from Gore's (and Reclus') vision is that users do not have to walk to a public space (i.e. the monster globe or the local museum) in order to access this information. They can do so from the intimacy and comfort of their homes, and, through new wireless technologies including mobile phones and ipads, from any spot within signal's reach. The new "digital globe" thus allows personal interactions with a virtual world giving "a powerful illusion of real presence that simultaneously distances us from the animate world and brings the locality of anywhere on earth into our immediate personal space" (Cosgrove, 2008, 1878). The following pages explore these interactions and their consequences.

\section{Telescopic vision}

Imagine, for example, a young child going to a Digital Earth exhibit at a local museum. After donning a head-mounted display, she sees the Earth as it appears from space. Using a data glove, she zooms in, using higher and higher levels of resolution, to see continents, then regions, countries, cities, and finally individual houses, trees, and other natural and man-made objects. (Gore, 1998)

11 The history of GE begins in 2004, with Google's purchase of the Keyhole Corporation, a digital mapping company with a multi-tera database of mapping information and satellite images. In the summer of $2005 \mathrm{GE}$ and Google Maps were launched on the web. A freely downloadable software, GE presents the globe as a patchwork of satellite and aerial images acquired by different sources at different times in different graphic formats to allow web-based mapping. As with Gore's Digital Globe, it allows to zoom in from the global to the topographic scale; it offers "the conceit of flying over the earth at altitudes ranging from outer space nearly 16k miles down to less than 100feet, [with a] resolution of at least 15 metres for most areas, although in some cities such as Las Vegas, Nevada, it is as high as $15 \mathrm{~cm}$ " (Cosgrove and Fox, 2010, 77). Satellite imagery blurs into aerial photographs through a continuous telescopic movement almost without the user realizes it. By a simple click of the mouse, street names and other layers of information are superimposed on the aerial views. Through a second click, the viewer is transported to street level.

12 Since 2005, these "pan and zoom 'slippy maps' have become an everyday part of life" for many (Crampton, 2008, 92)-we often just take them for granted. Yet, there is something unique and unprecedented about these maps. Whether to zoom in or to 
switch to Street View, clicking the mouse fulfills a two-thousand-year-old dream. This simple act merges two different traditions of spatial representation: the geographic and the chorographic. The difference between geography and chorography was captured by Ptolemy almost two millennia ago in his Geographikē Yphēghēsis, a sort of "mapping handbook".

The Alexandrian astronomer called geography "the representation, by a map, of the portion of the earth known to us, together with its general features" (Ptolemy, 1948, 162). Geography, Ptolemy explained, was different from chorography in that it implied the construction of mathematical models of the earth in which its surface was reduced to a set of geometrical points calculated through celestial coordinates; in other words, it transformed the earth's surface into an "orthonormal space, a potential archiving device in which a maximal number of places [could] be catalogued" (Jacob, 2006, 120). Chorography, by contrast, concerned itself "exclusively with particular regions and describ[ed] each separately, representing practically everything of the lands in question" (Ptolemy, 1948, 163). The former required mathematical training; the latter was the domain of the artist (Cosgrove, 2001, 102-5; see also van Passen, 1957). A third category, topography, was concerned with individual places and was defined by Ptolemy within a chorographic context (Lukermann, 1961, 196).

The difference between geography and chorography was thus not only one of scale (global vs. local). It was also a difference of mode: quantitative vs. qualitative, maths vs. art, space vs. place, specialized training vs. amateur skills. It was a difference of thinking too: analytic science vs. the art of memory, the grid vs. pictorial vignettes. Unlike geography, chorography (and topography) rested on memorable peculiarities of places; on sequences of vivid images, rather than on geometrical spatial constructs. Whether in paint or writing, chorography remained the privileged mode of spatial description throughout antiquity, the Middle Ages and the Renaissance.

Since the rediscovery of Ptolemy's writings in fifteenth-century Italy, this spatial hierarchy has come to characterize most of the history of western cartography. The first systematic attempt at harmonizing geographical, chorographic and topographic mapping comes from Abraham Ortelius. In his Theatrum Orbis Terrarum (1570), usually regarded by map historians as the first modern atlas, the Dutch cartographer integrated seventy maps cut to the same size and arranged according to a systematic spatial narrative that moved from the whole world, through its continents, down to individual regions and states. The Dutch cartographer referred to his maps as "charts being placed as if it were certaine glasses before our eyes" (quoted in Alpers, 1987, 88). The movement from one page to the next allowed a horizontal movement through places and regions, as well as a telescopic scalar movement. At the same time, while mathematically coordinated, maps struck their viewers for their vivid and thus memorable features. Thanks to their visual power, they allowed the viewer to access distant places without making him travel [Fig. 1]. 


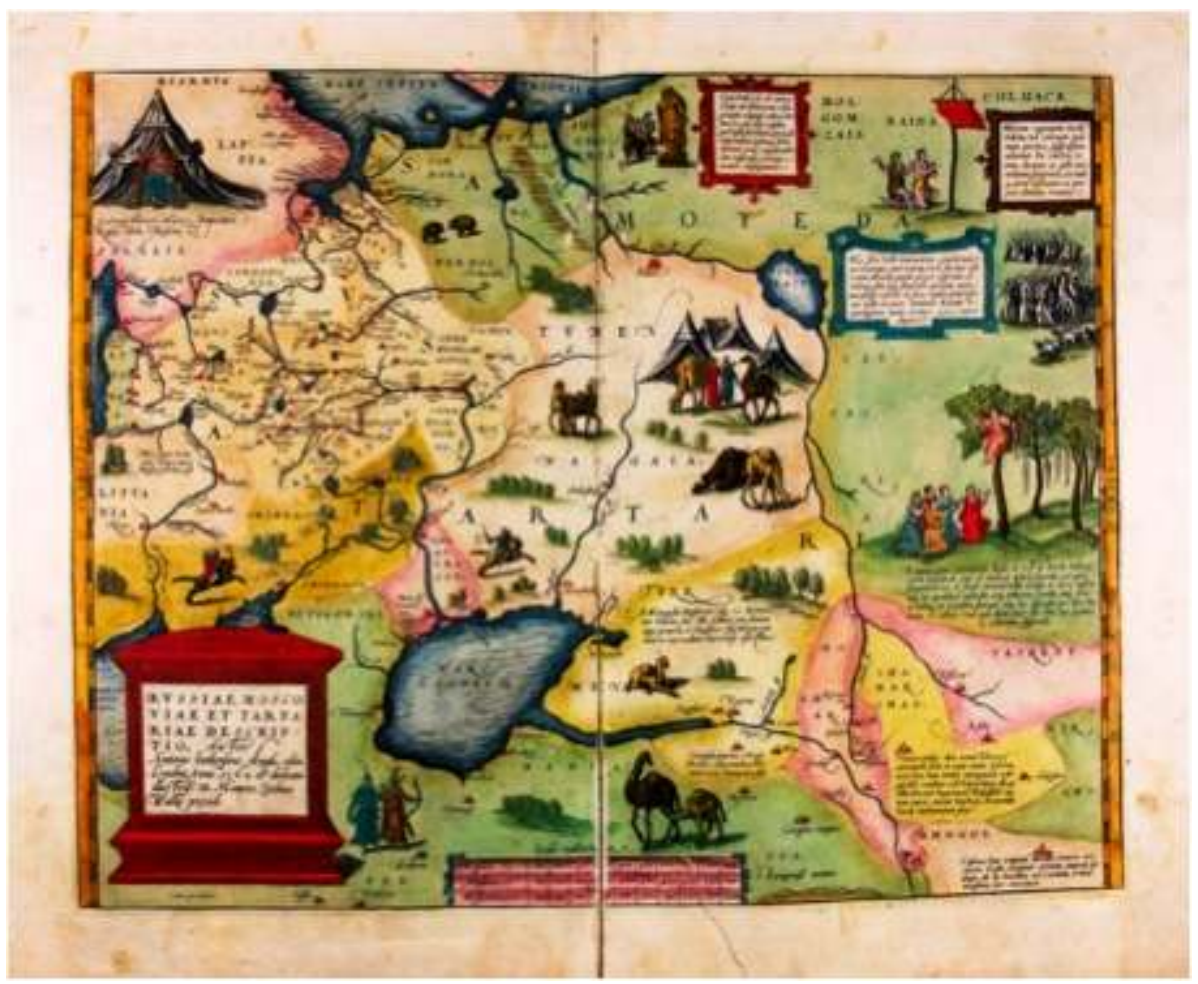

Figure 1. Chorographic map of Moscow and Tartary from Abraham Ortelius' Theatrum Orbis Terrarum, 1574 (Courtesy of the University of Bristol Library Special Collections).

Modern atlases might have lost the pictorial, chorographic quality of monsterpopulated Renaissance maps. Rich cartouches and colourful memory places/vignettes have been substituted by legends listing standardized symbols and by crowded naming -both conveying cartographic science's "rhetoric of truth" [Fig. 2].

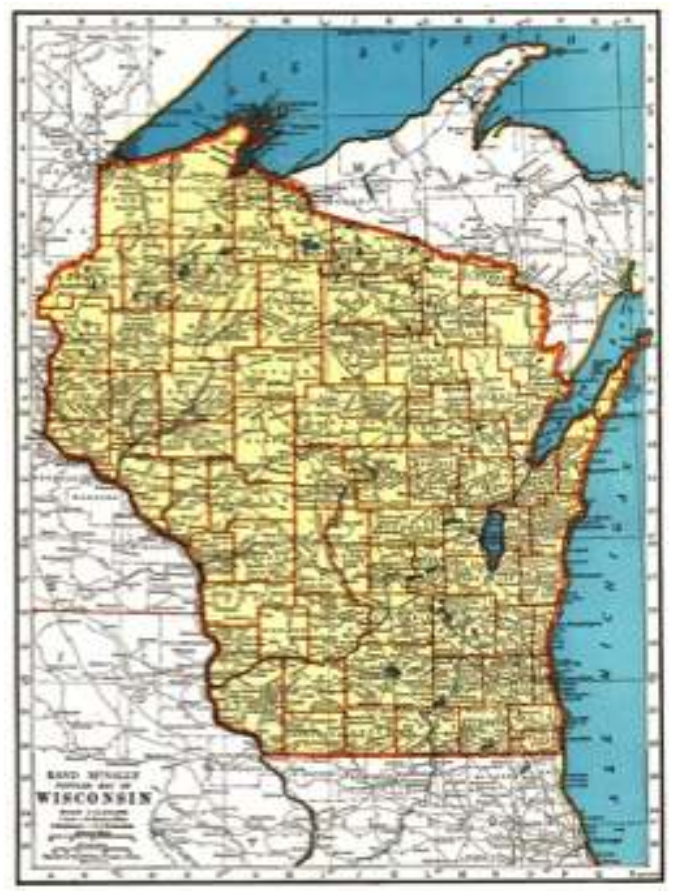

Figure 2. Rand McNally map of Wisconsin, 1944 (author's personal collection). 
Yet, their scalar organization (world-continents-states-regions) continues to follow the Ortelian model. GE fulfills and exacerbates this telescopic illusion, the ability to zoom from global to local and commute to street level-from map to landscape. This movement produces a new "rhetoric of truth". "Slippy" maps give the viewer total navigational freedom, reinforcing the daydream of cartographic transparency. "The Enlightenment goal of coordinating the image of the world at scales ranging from the topographic to the global has been achieved through a commercial search engine" (Cosgrove, 2010, 106).

18 The perception of GE as a cartographically transparent medium is reflected in a variety of comments populating users' blogs. Evert Schut, a Dutch expressionist painter inspired by and working with GE imagery, for example, writes:

Satellite images are not new; specialised companies were putting out satellite images years ago. Of course, an artist could have chosen to make his own interpretation. But it was someone else who made the original shot. With GE you as the artist can choose what to shoot..., from which height, angle position, etc. So GE as a programme is an essential tool for the artist, just like a camera for the photographer. What you do with the image is your own choice as an artist. (http:// googleearthphilosophy.blogspot.com/; my italics)

Unlike traditional satellite photographs, GE images here are perceived as user's, rather than satellite, creations. Their "slippiness" is conducive of a strange process of naturalization, whereby one is led to forget that GE is indeed a large (and carefully edited) collage of those very images; that "the remote sensed image is a product of colouring choices applied by the mapmaker to pixels received by the cartographic studio in numerical, digitized form" (Cosgrove, 2008, 162) in order to make the picture easier to read and more realistic; and finally, that (aerial) photography itself is a constructed representation of reality. The fact that the earth is "smashed to smithereens, shamelessly manipulated [and packaged in] endless codes" (Wood, 2002, 54) is obscured by the artist's re-interpretative act; it blurs in the scalar movement from geographic to chorographic representation. As images appear "transparent" and "unmediated", a new spatial vocabulary and imagination of the world is developed. The abstraction of topographic cartography, with its coded symbols, is replaced by the illusion of immediacy conveyed by photography; cartographic selectivity by customization.

\section{Cartography for all?}

My other reason for choosing GE Art is the importance of the internet in connecting people to each other. GE is in my mind the first step to connecting us to our planet. (http://googleearthphilosophy.blogspot.com/)

Besides blurring boundaries between scales and representational modes, thus reinforcing the illusion of transparency (and seemingly "connecting us to our planet"), "slippy maps" blur the traditional boundaries between map user and map maker, the trained professional and the map amateur ("connecting people with each other"). Much of the new digital mappings' content is user-generated and globally distributed. Customers are given the opportunity to create placemarks (geographically referenced annotations, including texts and images), routes and overlays to be shared with the online community. This can be envisaged as part of a broader shift in the creation and distribution of knowledge, whereby online sources and collaborative web tools, such as 
wikis, blogs, image albums and social networking sites, are superseding (or complementing) traditional printed repositories of knowledge (e.g. printed atlases, dictionaries, encyclopaedias and other reference books). At the base of this shift in the production and distribution of knowledge is not so much the technology itself as the way in which technologies are integrated, originating "new modes of information creation, discovery and sharing" (Johnson, 2011, 267).

Some contemporary commentators identify in the "democratization of mapping" another major area of epistemic rupture with traditional cartography. For most its history, Crampton argues, mapping has been confined in the hands of powerful elites (rulers, governments, the army, etc.). Yet, this "sovereign map paradigm" (Jacob, 2006), some argue, is now being challenged by "a new populist cartography in which the public is gaining (some) access to the means of production of maps" (Crampton, 2010, 26). Sarah Elwood speaks of a true paradigmatic shift from a model in which national governments were the lead actors in producing spatial datasets towards patchwork datasets produced by citizens, states and private entities, and largely based on volunteered information (Elwood, 2010, 351). "Cartography for all" is GE's new slogan (http://oneworldmanystories.com/1_billion.html).

22 While access to these technologies is unevenly spread across the world and western societies (Crutcher and Zook, 2009), with notable gaps between developed and underdeveloped countries, as well as between computer-literate and -illiterate generations (Crampton, 2003), the new web-based mappings have an extraordinary outreach potential-by May $2011 \mathrm{GE}$ alone had hit over one billion downloads (http:// googleblog.blogspot.com/2011/10/google-earth-downloaded-more-than-one.html).

These data are fuelled by discourses permeated by a strong rhetoric of democracy and at the same time emphasizing personalization: free accessibility and co-authorship; public participation and individual needs; global involvement and customization (Crutcher and Zook, 2009).

23 Such rhetoric permeates map design. Unlike the classical world map opening traditional paper atlases, GE's opening screen presents us with an orthographic rendering of the globe which can be centred on the customer's location and spun around. Unlike cartographic projections, the sphere does not privilege any specific place: all the points on its surface are equidistant from its centre. It speaks of human unity, rather than (like, say, the Mercator projection) supremacy of a certain region over another (see Harley, 1988). It sets "you", the customer, at the centre of a "just" planet and invites you to interact with it. Furthermore, the GE globe presents a naturalistic world without differently coloured nation-states-political boundaries are just another layer rather than a reality. In other words, GE presents itself as a utopian project of global tolerance akin to nineteenth century monster globe projects. As Dodge and Perkins commented in a recent editorial, "the avowedly naturalistic look of the virtual globe shrouded in satellite imagery is beginning to replace the world map of nation-states as the default meta-geography of the media" (Dodge and Perkins, 2009, 497) - and to shape popular geographical imaginations accordingly.

Some commentators have compared the revolution brought by geoweb technologies to the invention of the PC: just as the latter democratised computing, so the former is democratizing GIS (Butler, 2006, 777). Yet, these public, citizen-oriented mappings embed tensions and paradoxes: while opening new possibilities for counter-mappings and counter-knowledge (Crampton, 2009, 91), they ultimately remain the domain of 
digital corporations, as the Google logo at the bottom of each GE map silently reminds the viewer. Hence, while GE appears to be a free good, open to all, "its goal is about (re)constructing a political economy of cartographic information that will drive profits into the coffers of a new class of mapmakers" (Dodge 2013). Like it or not, the photographs uploaded by individual users become property of Google, who reserves the right to cut and edit inappropriate images. In this sense, mapping ultimately remains in the hands of (neoliberal) "princes and rulers"-simply under a different guise and through different modalities.

On a macroscale, as nation-states lose their ability to control the production and circulation of images of their territories, "Google Earth transforms the sovereign territories of all the world's nation-states into visual, digital, navigable and privatized domains (largely) owned by a US corporation... [It] is not a view from nowhere-it is the view from a company with enormous visual capital" (Parks, 2009, 541). On a microscale, Google Maps and Street View users are piloted towards certain businesses rather than others. As with any maps, Google has the means to highlight and downplay places and activities in its maps (Zook and Graham, 2009, 472).

Whether at a global or street level, Google mappings produce utopian freedom and at the same time panoptic control (Kingsbury and Jones, 2009; Connor, 2010). Intriguingly, as debates about violations of privacy rights proliferate in newspapers and blogs (from military bases and sunbathing nudists captured by GE to Street View cameras intruding home spaces), an increasing number of users daily uploads images and other information on GE and related blogs, including personal information (Cosgrove and Fox, 2010, 77). ${ }^{4}$ These, Crampton notes, are people coming from different pathways of life who "nevertheless want to share their lives with friends. And they know for that, they'll need to include the geographies of their everyday lives" $(2010,25)$. Yet these networks go well beyond personal acquaintances to virtually encompass every user around the globe. GE offers itself as a space for a collective "cumulative" mapping enterprise superficially reminiscent of Reclus' "universal geography" to which every user was encouraged to contribute. As a result, The New York Times comments, map amateurs "are reshaping the world of mapmaking and collectively creating a new atlas that is likely to be both richer and messier than any other" (quoted in ibid.).

\section{Georeferencing: memory and memorialization}

As with other crowd-sourced databases, such as Wikipedia, this "new atlas" is redrawing the boundaries between cartographic professionalism and amateurism (Crampton, 2009, 92). Unlike Google Maps, GE is not so much designed for way finding as for collective information storage, virtual travel and public interaction. In its "creative messiness", it is somewhat akin to a vast Renaissance cabinet of curiosities (della Dora, 2009). While resting on the "rhetoric of truth" traditionally ascribed to geographical science (rooted in Ptolemy's mathematical models), ironically, at the same time it also re-awakens the older chorographic tradition-the user is invited to navigate the world as a sequence of memory-places.

While modern world maps are usually snapshots of a specific moment in history, GE integrates visions of the past, present and future (as with pre-modern mappings). Shrouded in cartographic transparency, its compositional rhetoric is ironically akin to that underpinning Medieval mappae mundi[Fig. 3]. 


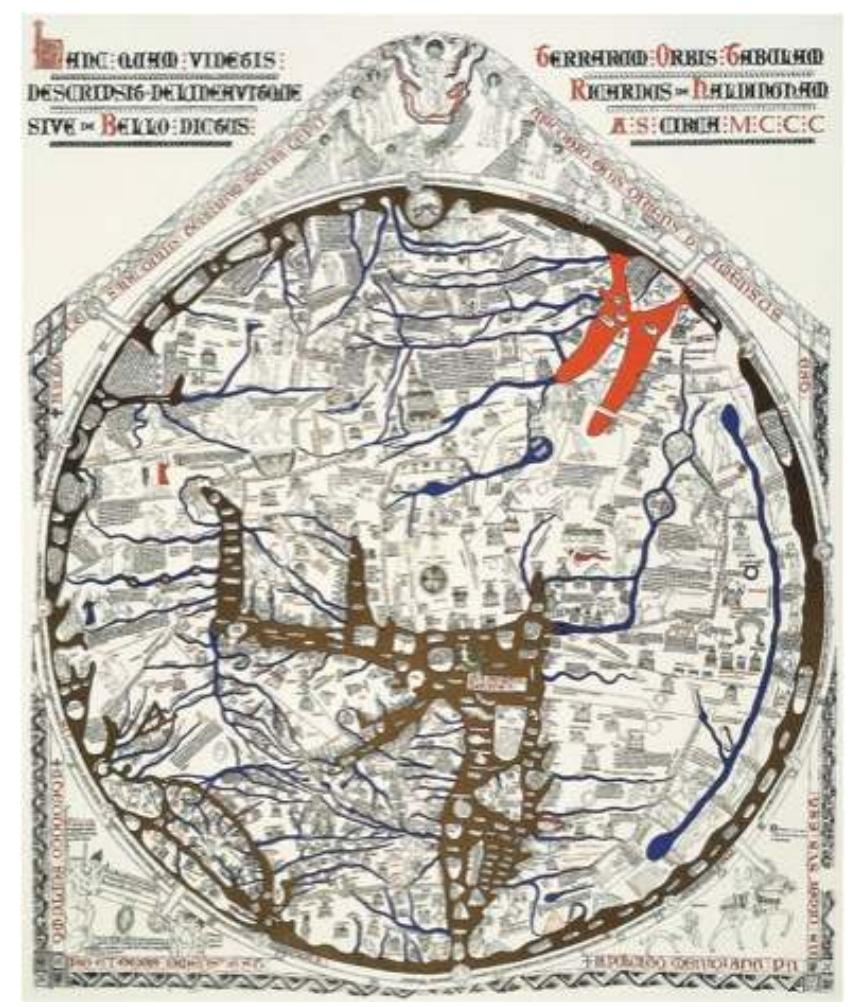

Figure 3. Reproduction of the Hereford mappa mundi, late $13^{\text {th }} \mathrm{C}$. (wikimedia). principle, which GE has inherited. The globe metaphor, the vice president explains, is the most suitable to organize information: "Things are easier to memorize if spatially related to one another; the human brain cannot retain more than seven pieces of information in short term memory, ... but can absorb billions of data if arranged in recognizable patterns within which each bit assumes meaning in relation to other bits" (Gore, 1998). By creating spatial associations on a virtual globe (or indeed on any map), geo-referencing facilitates memorization. Rather than a cumulative enterprise, contemporary knowledge-making can be characterized as a locational one; as an endless search to fix and retrieve things, ideas and encounters in (virtual) space.

, increasing numbers of individual users upload information on GE virtual globe. They find in it a space for "free speech", or what Crampton called parrhēsıa (Crampton, 2003). Through the act of uploading, personal information is made public. Adding placemarks, photographs, and YouTube videos on GE may be justified as a collective effort to build a "better map". In reality, however, this is primarily a way to put oneself on the map. It is a way to commemorate a moment in life or a visit to a place. It is a way to validate the authenticity of the visit by leaving a mark on the virtual globe. Personal 
experiences are "pinned down" (and perhaps forgotten) through the paradoxical act of "inscribing" a transient geographical surface.

The most obvious example are the dozens of nearly identical photographs of the same landmark (usually a tourist attraction) [Fig. 4].

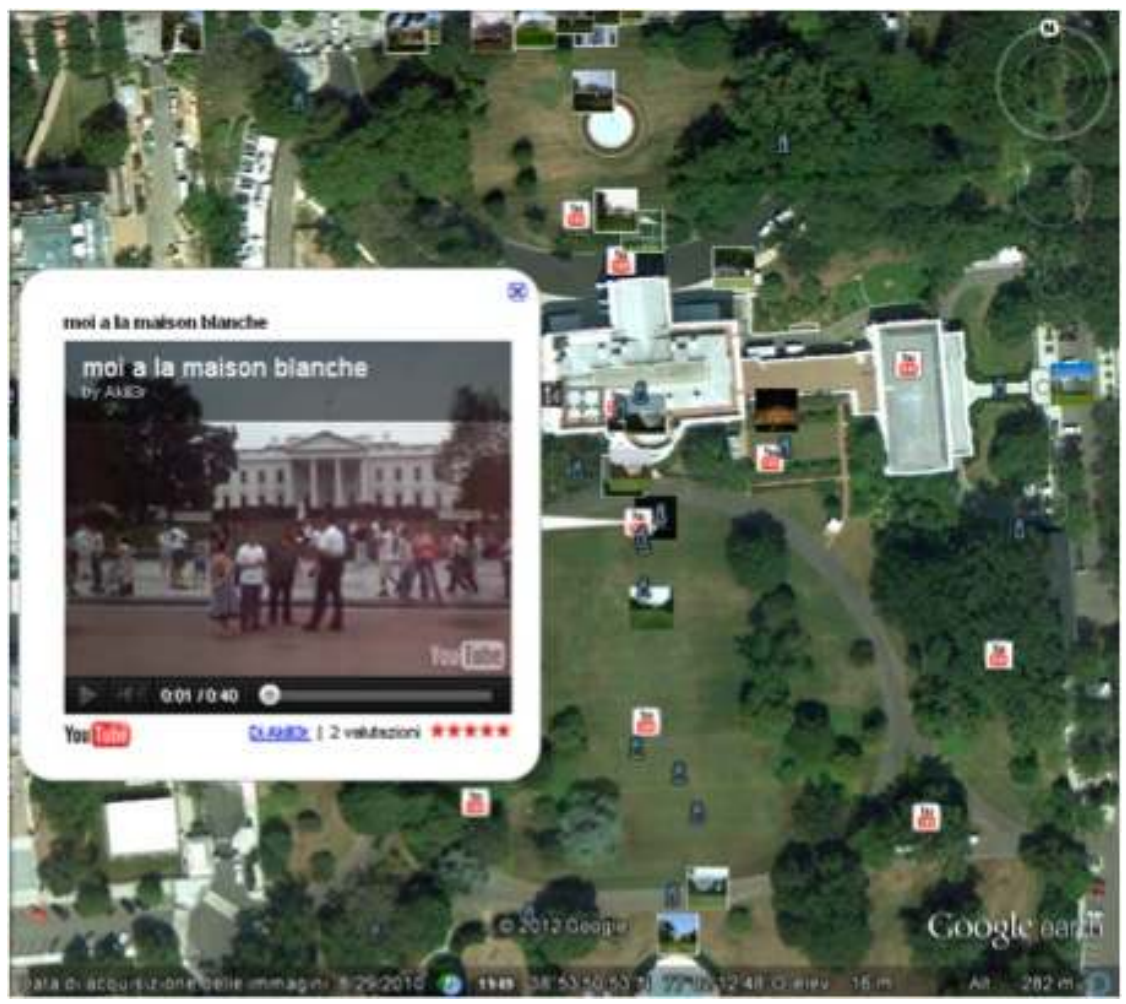

Figure 4. Mapping oneself on the White House (GE, retrieved on Jan. 21, 2012).

This, of course, has no practical function other than "mapping" a memory and letting the world know that "I have been there", or simply becoming "a participant in the news [rather than a reader]" (ibid., 106). The virtual globe thus finds itself in a continual state of becoming, and yet at the same time it is ironically used to store memories. Videos of happy newlyweds, smiling babies, concerts, car races and other geo-referenced place-events act as the old mappa mundi's loci memoriae. They fix a temporal event in space. The old Ptolemaic distinction between geography and chorography is once again blurred-and not just in terms of scale.

"Placing" the self on the world map can be interpreted as a process of selfidentification, as well as an act of memorialisation. As such it encapsulates a sense of nostalgia that various scholars have identified as a characteristic condition of contemporary western societies, something akin to tourists' obsession with picturetaking (Davidson et al., 2011). GE functions as a global archive bringing ghostly nonpresences to life. It magnifies photography's function as memento mori; as a device for capturing and freezing a moment, and, by doing so, testifying to time's relentless melt (Sontag, 2001 [1977], 15). The most emblematic example is probably the site of Ground Zero, crowded as it is with photographs of the Twin Towers-from the 1970s to "nine days before the attack" [Fig. 5]. 


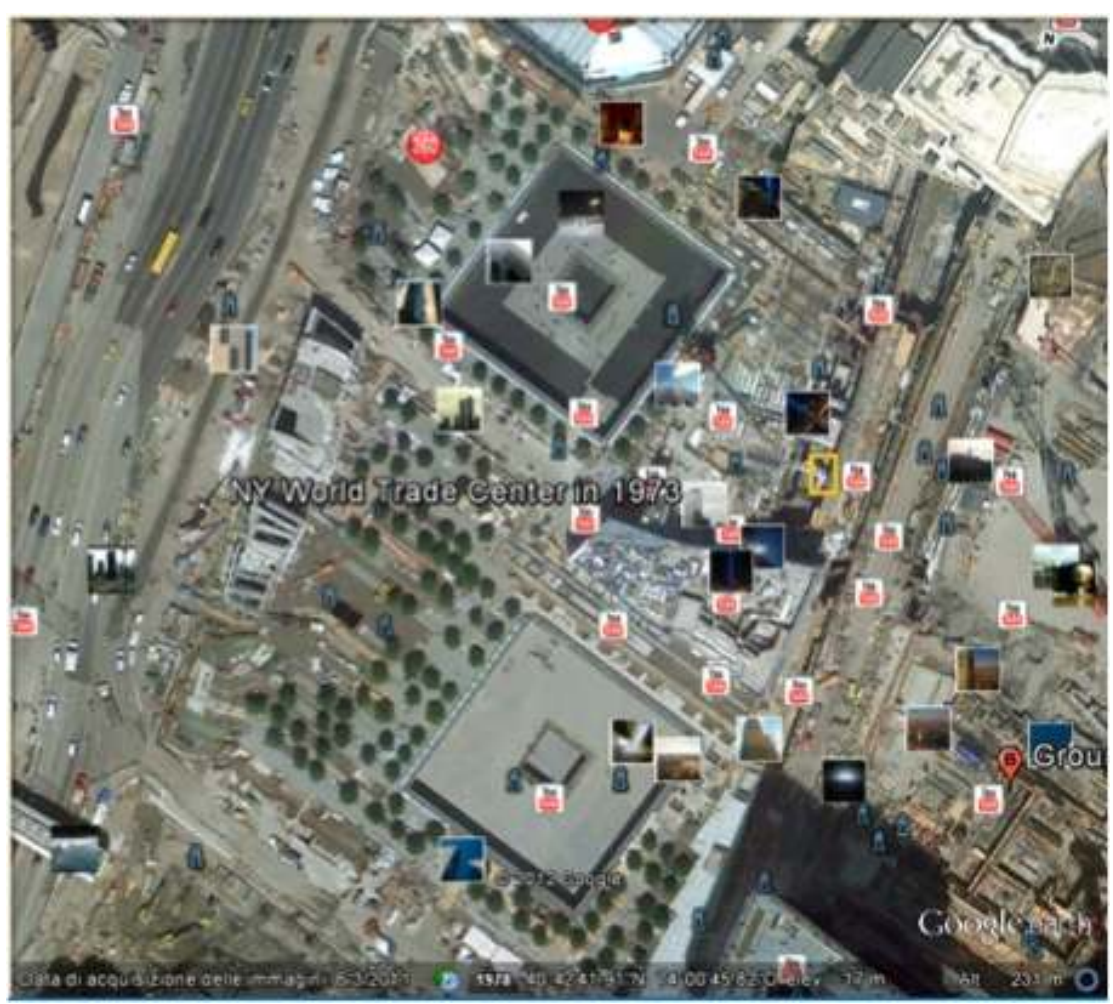

Figure 5. The site of Ground Zero (GE, retrieved on Jan. 12, 2012). environmental organizations (e.g. the United States Holocaust Memorial Museum, WWF, etc.) obey the same rhetoric as "memory places" created by individual users. A particularly dramatic example is "Appalachian Mountain Top Removal", characteristically subtitled "National Memorial for the Mountains". This layer was produced by the grassroots association Appalachian Voices in 2007 to alert public opinion on the removal of mountain tops in the Appalachian region and the consequent devastation of local communities. "Mountaintop removal coal mining is changing the American landscape on a scale that is hard to comprehend unless you see it from the air", the authors of the layer explain,

Anyone who has ever flown in a small aircraft over southern West Virginia or eastern Kentucky will never forget the experience of seeing the massive scale of destruction-mountain after mountain blown up and dumped into valleys as far as the eye can see. Mountaintop removal affects more than mountains and streams; however it is threatening to displace and destroy a distinctly American culture that has persisted in the Appalachian Mountains for generations. (http:// earth.google.com/outreach/cs_app_voices.html)

The layer blends dramatic views of the blown mountain tops with first-person testimonies by members of local communities such as the following:

McRoberts, KY: After mountaintop removal coals mining started above the community of McRoberts, KY, the community experienced three-hundred-year floods in ten days. Local resident Lucious Thompson ... describes the devastation this way: "The good things disappearing are the trees, the wildlife. (...) Years ago was wall-to-wall people. Everyone had a job. The way it's going now, no one's ever 
going to have a job in this area. I figure in 10 years it will be a ghost town. Tumbleweeds will be going down the road. This place will never be like it used to be". and black and white photographs of locals [Fig. 6], the layer speaks in a sort of visual past tense.

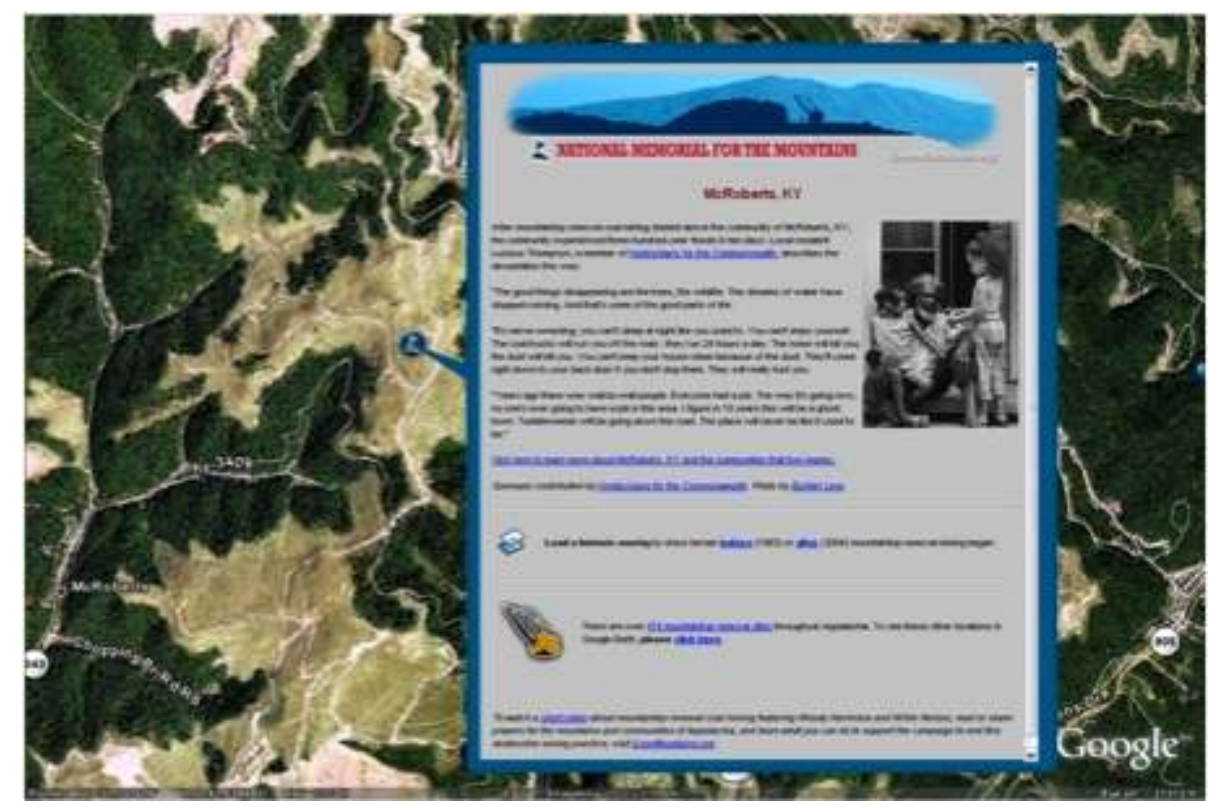

Figure 6. Appalachian Mountaintop Removal (GE, retrieved on Jan. 12, 2012).

Unlike TV news which claim to be "live" or "up-to-the-minute", it functions as an archive of events observed as they unfolded "but without intervention". It perpetuates an "a-historical logic that presumes there are never changes to conditions there" (Parks, 2009, 540). As with placemarks featuring shots of places that are no longer there and videos of moments in individual lives, in their temporal indeterminacy, overlays collectively speak a sense of nostalgia-for a lost nature, for a lost sense of community. The (virtual) globe has become a vast memorial of itself.

\section{Turning the world into a (fancy) map}

Nostalgia for an indeterminate past is not the only affective dimension engendered by GE. As with medieval mappae mundi featuring current cities, past Biblical occurrences and (future) apocalyptic events, the virtual globe embeds multiple temporalities. Besides the indeterminate past tense of satellite photography and overlays, GE also speaks in an indefinite present-future tense. Not only does it feature images of places that are no longer there, but it also encompasses (and thus makes real) places that are still in becoming or places that are not even there yet, such as artificial islands or buildings under construction. Many of these sites are purposely engineered to appear aesthetically appealing to GE users and more likely to capture the attention of armchair explorers during their virtual wanderings. Hence, $\mathrm{GE}$ is also a medium for planning, for shaping spaces and futurities. It is an online archive that is somehow contributing to transform the offline world. 
To tour a typical American downtown with GE, a Los Angeles Times article commented in 2006, is "to see a collection of roofs that either sit forlornly empty or are littered with rusting mechanical equipment-a lack of architectural attention that can be traced to the rise of the Modern movement a century ago" (Hawthorne, 2006). Yet, since the launch of GE the trend has reversed. Over the past few years, architects have paid special attention to roofs, viewing them as the "fifth façade" of a building-"a place to get creative and decorate for those millions of people world-wide who may view your buildings from above". Among other examples, the LA Times article mentioned the new de Young museum rooftop in San Francisco to be covered in long, thin skylights and copper panels (then viewable under construction in GE) and a satellite image centred on the museum's observation tower, described as "a wry twist on the idea of the observation tower in an age of digital technology and pervasive surveillance-a reminder that while you are looking down on the world, the world is also looking down on you" (Hawthorne, 2006).

Other post-GE architectural trends include "green roofs" featuring gardens or parks on the top, and artistically decorated roofs. Hence, "while US Secretary of Energy Stephen Chu would like us all to paint our rooftops white-sending excess heat and blinding glares back into space", artists such as New Yorker Molly Dilworth are producing colorful rooftop paintings that can be seen from outer space (http://inhabitat.com/ stunning-rooftop-paintings-that-can-be-seen-from-satellites/) [Fig. 7]. ${ }^{5}$

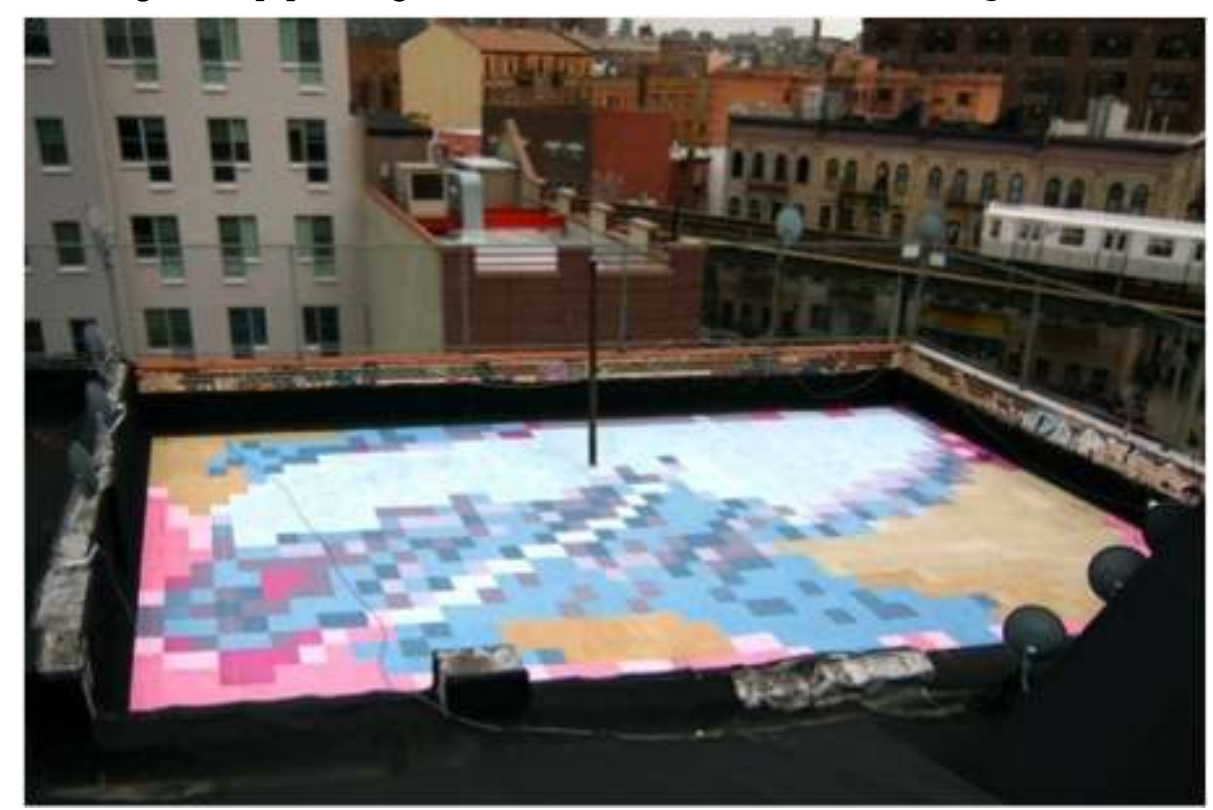

Figure 7. Molly Dilworth's painting for satellite

(source: http://inhabitat.com/stunning-rooftop-paintings-that-can-be-seen-from-satellites/).

Conversely, when in 2007 the ground plan of a 1950s US Navy building on Coronado Island in San Diego was shown from GE images to take the form of a swastika, the whole site was modified by vegetation planting at a cost of six-hundred thousand dollars-a testament to the pervasiveness of the panoptic "view from above" (Cosgrove and Fox, 2010, 77).

As these examples suggest, spatial design, technology and social life are closely intertwined (Dave, 2007, 381). Yet, they often are in ways that defy conventional logics. Where urban planning in North America has been traditionally dominated by the 
practicality of the rectilinear grid-a metaphor for modernity-the new GE-inspired planning projects are utterly impractical. Take a plan of Washington DC or any other American city-rectilinear, rational, easy to navigate [Fig. 8].

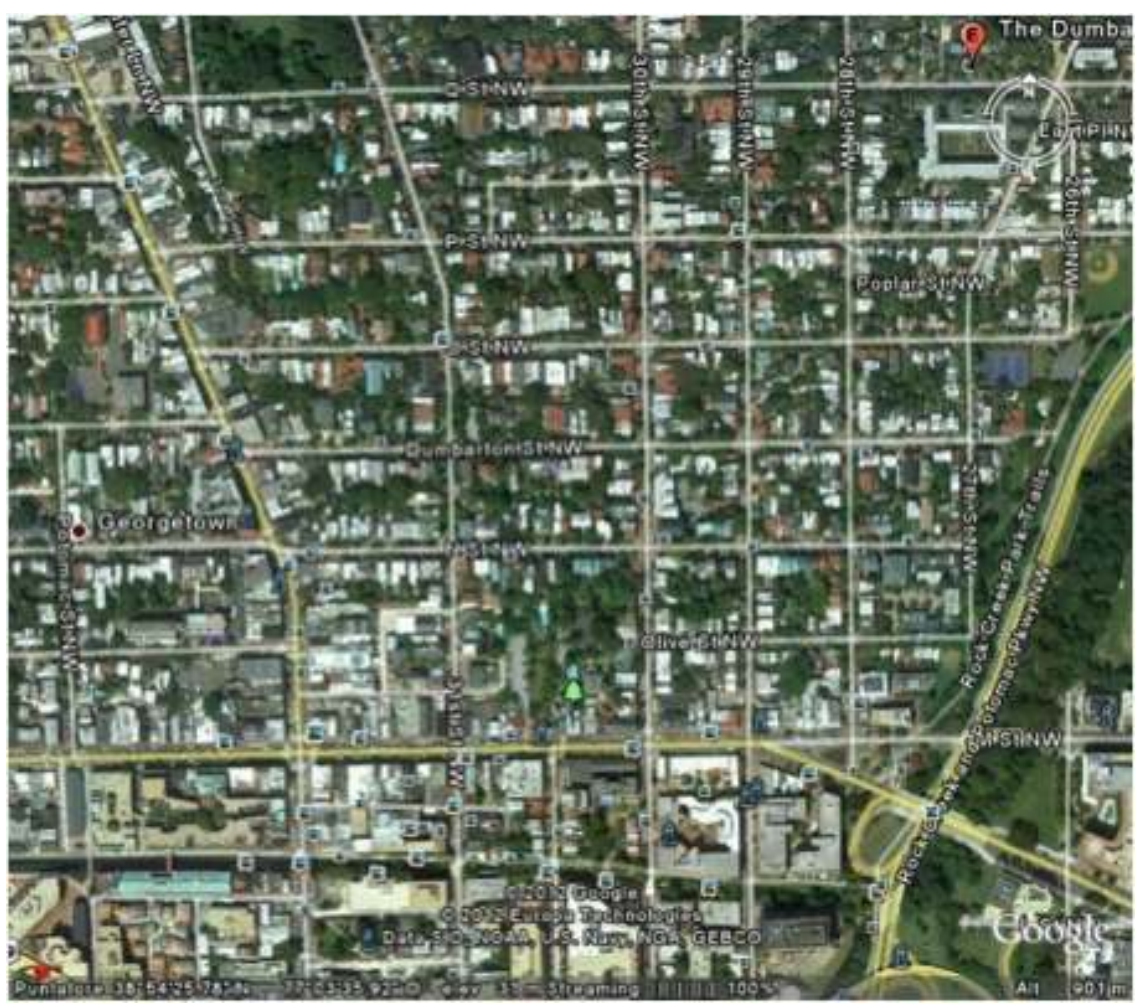

Figure 8. Georgetown, Washington DC (GE, retrieved on Jan. 2012).

Welcoming, according to Yi-Fu Tuan $(1999,94)$. Or zoom out and take the agrarian landscapes of the Midwest and the Plains dominated by die-straight property lines and field boundaries. These rectilinear forms stand in sheer contrast with the fancy shapes of the above-mentioned rooftops and even more so with the fractal forms of the new artificial islands which have emerged off the coast of Dubai over the past few years [Fig. 9]. 


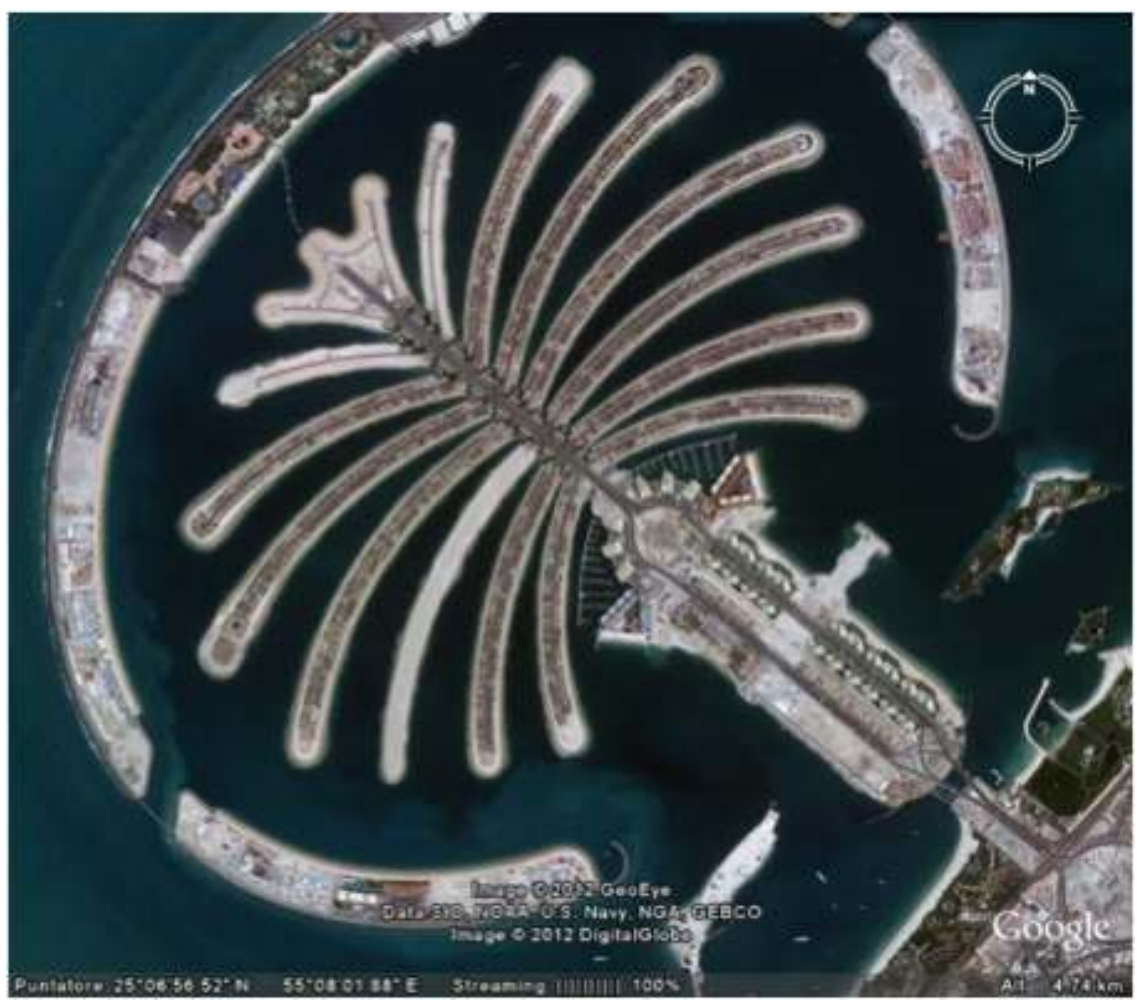

Figure 9. Palm Jumeirah, Dubai (GE, retrieved on Jan. 2012).

The traditional American and new Emirate landscapes both make sense from above. The former found their fulfillment in the early twentieth-century air view; the latter in the development of GE. Yet, these landscapes also present differences. In earlytwentieth-century America the dream of flight, offering "an Apollonian perspective of the wide earth", Cosgrove comments, "encouraged visions of spatial order to be written across the land, free from the hindrance of local contingency and variation" (Cosgrove, 2008 , 89). It allowed rational control producing an open, predictable, replicable, if not monotonous landscape. By contrast, the Gulf palm-shaped islands and neighbouring world-map archipelago are built to strike, to be memorable icons. They are giant curios engineered to capture attention. Practicality has been overcome by aesthetics; predictability by wonder.

The ideologies and politics underpinning the airman and GE-generated landscapes are likewise different:

Opening American space in equally sized parcels, at an affordable price, to individual farmers appeared the precondition for a stable and open democracy. The rectangular grid is the perfect spatial expression of the new republic's democratic imperative. (...) The rectangular grid is space-equalizing. It privileges no one point above any other; it distributes power equally across space. It is the landscape measure of America's commitment to life, liberty and the pursuit of happiness. (ibid., 94)

Insular spaces, by contrast, imply enclosure, miniaturization, and privacy, rather than openness and democracy-and in fact the Gulf artificial islands are marketed and sold as private property. They embody contemporary geographical specificities of exclusivity, consumption, leisure, investment, and escapist fantasy. Rather than "ordering" the world, they are engineered as refuges from a world that is perceived as "full" and irremediably corrupt. Coming in the most improbable forms, at the same 
time, these insular utopias present themselves as "the new cultural icons": a "must" for aspiring "global cities" striving to get to the centre of international attention (Dematteis, 2001; Jackson and della Dora, 2009, 2088). If the American grid was an icon of democracy, the Emirate fractal utopia is an icon of new neoliberal economies.

According to Italian geographer Franco Farinelli (1992), modernity started with rectilinear inscriptions on territory (roads, railroads, canals, political boundaries, etc.); with the transformation of the world into a map, which is, into a representation of itself. Spaces like the Gulf artificial islands or the fancy American rooftops fulfill and yet the same time transcend this project: not only do they participate to build the world as an aestheticized cartographic image, but they are visually accessible only through technological mediation. Designed as memorable iconic forms to be viewed from above, they remain invisible from ground level.

If the cultural landmarks of modernity were overwhelmingly vertical landmarks (the Eiffel Tower, the Empire State Building, the Twin Towers), and the fancy icons of postmodernity were equally visible (Los Angeles's Bonaventure Hotel, Vegas' Luxor and Cesar Palace, Bilbao's Guggenheim), these new cultural icons aspire to flatness. The private islands forming The World archipelago in Dubai are nearly invisible from the coast. "The rationale is that exclusivity demands as complete a visible separation, if not actual, as possible: in other words, the illusion of separation" (Jackson and della Dora, 2010, 2092). These iconic spaces are engineered to be visually consumed only through the synoptic mediation of the same technologies through which they were conceivedperhaps the ultimate expression of GE's detached way to interact with the built environment.

\section{Conclusions: revolution or evolution?}

51 As with any map, GE is a project on the world. As such, it has the potential to shape geographical imaginations and, at the same time, to shape territory to its own image. It has also the power to shape our relationship with offline space. Yet, digital topologies of memory and their naturalization through telescopic vision are shaping our perception and transformation of the world in new ways. Through GE we experience "presence at a distance" (Dicks, 2003, 176). As events are transformed into place-events and places into placemarks, our relationship with the world and distant others is reduced to a detached, disembodied verbal and image-based exchange: like the television, GE encourages "a non-committal relation with the world, a zapping domain where everything is watchable rather than graspable" (ibid., 191).

While traditional paper maps left a margin for interpretation and imagination, "slippy" GE images are taken for granted, uncritically, as "truth" (forgetting that they are also constructed). GE users are thus less inclined to "pause" and think than frantically move around and look for new, more exciting pictures. Unlike paper world maps, the virtual globe is not conducive of quiet meditative contemplation, but rather of anxious wandering, unplanned random movement, improvisation-what Paul Kinsbury and John Paul Jones III called "Dionysian intoxication" (Kinsbury and Jones, 2009). In this new economy of space visually striking curios such as fancy rooftops or, on a larger scale, fractal artificial islands, engage in a restless global competition to win GE users' attention-and thus the attention of the media. 

not only our way of imagining distant places, but also of perceiving and interacting with our immediate environment. As iphones, ipads and other mobile devices multiply, slippy mapping is becoming more and more pervasive. An "ecology of screens" is silently wrapping the earth-a vast geographical web of perception that crowds our daily lives, "communicating, informing, entertaining, affecting life" (Thrift, 2005, 233). Besides enframing places, screens flatten them. Unlike GE derives, conducting a Google Maps search via a mobile phone to find a local business, or using Street View to identify the hotel of our next travel destination are practical acts of orientation intertwined in everyday pragmatics. Yet, as with GE, they eventually produce a distanced and "flattened" topological perception of the environment-just from a different perspective. Landscape is experienced as a sequence of loci, rather than as a synoptic coherent view. We are encouraged to think about places in terms of de-contextualized landmarks and snapshots, rather than distances and prospects-an uncanny return to premodern chorography.

Yet, this is no value-free chorography. For example, as consumers are becoming more and more reliant on Google Maps and Street View to find shops and services, large corporate businesses are usually favoured and smaller ones without internet are inevitably marginalized (Croutcher and Zook, 2009, 472). As Bella Dicks argued, "the digital image is not a substitute for the real object, nor is the real object in a different form. In fact, it is not material at all but rather a metaphor for the real (we have learned to naturalize this metaphor by coming to accept that bytes can stand for atoms)" (2003, 185). Google Earth and slippy maps best embody this metaphor. Yet, as this essay has shown, metaphor and reality are not separated. They are rather intimately intertwined, constantly feeding each other. The extent and the consequences of this interaction though are yet to be mapped.

\section{BIBLIOGRAPHIE}

ALPERS, Svetlana, “The Mapping Impulse in Dutch Art," in Art and Cartography: Six Historical Essays, David Woodward, ed., Chicago, Chicago University Press, 1987, 51-96.

BROCKINGTON, Grace, Internationalism and the Arts in Britain and Europe at the Fin de Siècle, Oxford, Peter Lang, 2009.

BUTLER, Declan, “The Web-Wide World,” Nature 439 (2006): 776-78.

CONNOR, Ben, The Virtual Flâneur? Exploring Google Street View, unpublished MSci thesis, Bristol, University of Bristol, 2010.

COSGROVE, Denis and FOX, William, Photography and Flight, London, Reaktion, 2010.

COSGROVE, Denis, "Images and Imagination in $20^{\text {th }}$-Century Environmentalism: from the Sierras to the Poles," Environment and Planning A 40 (2008): 1862-80. 
COSGROVE, Denis, "Mapping the World," in Maps: Finding Our Place in the World, James Akerman and Robert Karrow, eds., Chicago, University of Chicago Press, 2010.

COSGROVE, Denis, Apollo's Eye, Baltimore, Johns Hopkins University Press, 2001.

COSGROVE, Denis, Geography and Vision, London, IB Tauris, 2008.

CRAMPTON, Jeremy, “Cartography: Maps 2.0,” Progress in Human Geography 33 (2009): 91-100.

CRAMPTON, Jeremy, "Keyhole, Google Earth, and 3D Worlds: An Interview with Avi Bar-Zeev," Cartographica 43 (2008): 85-93.

CRAMPTON, Jeremy, The Political Mapping of Cyberspace, Edinburgh, Edinburgh University Press, 2003.

CRAMPTON, Jeremy, Mapping: A Critical Introduction to Cartography and GIS, Malden, MA, Wiley-Blackwell, 2010.

CRUTCHER, Michael and ZOOK, Matthew, "Placemarks and Waterlines: Racialized Cyberspaces in Post-Katrina Google Earth," Geoforum 40 (2009): 523-34.

DAVE, Bharat, "Space, Sociality and Pervasive Computing," Environment and Planning B: Planning and Design 34 (2007): 381-82.

DAVIDSON, Tonya et al., eds., Ecologies of Affect: Placing Nostalgia, Desire and Hope, Waterloo, ON, Wilfrid Laurier University Press, 2011.

DELLA DORA, Veronica, "Performative Atlases: Memory, Materiality and Co-Authorship," Cartographica 44 (2009): 241-56.

DEMATTEIS, Giuseppe, "Shifting Cities," in Claudio Minca, ed., Postmodern Geography: Theory and Praxis, Oxford, Blackwell, 2001, 113-28.

DICKS, Bella, Culture on Display: The Production of Contemporary Visitability, Milton Keynes, Open University Press, 2003.

DODGE, Martin, book review of Jerry Brotton's The History of the World in Twelve Maps, forthcoming in Environment and Planning D: Society and Space, 2013.

DODGE, Martin and PERKINS, Chris, "The 'View from Nowhere'? Spatial Politics and Cultural Significance of High-Resolution Satellite Imagery,” Geoforum 40 (2009): 497-501.

ELWOOD, Sarah, "Geographic Information Science: Emerging Research on the Societal Implications of the Geospatial Web," Progress in Human Geography, 34 (2010): 349-57.

EVA, Fabrizio and FERRETTI, Federico, "Petr Aleksejevich Kropotkin (1842-1921)" in Cos'è il mondo? È un globo di cartone: insegnare geografia fra Otto e Novecento, Marcella Schmidt, ed., Milano, Unicopli, 2010, 131-60.

FARINELLI, Franco, 1992. Segni del mondo. Firenze, Scandicci.

FERRETTI, Federico, “Élisée Reclus (1830-1905), in Schmidt, Cos'è il mondo?” in Cos'è il mondo? È un globo di cartone: insegnare geografia fra Otto e Novecento, Marcella Schmidt, ed., Milano, Unicopli, 2010, 103-29.

GORE, Al, "The Digital Earth: Understanding Our Planet in the $21^{\text {st }}$ Century", speech given at the California Science Center, L.A., 1998, available at: http://www.digitalearth.gov/VP19980131.html GORE, Al, An Inconvenient Truth: The Crisis of Global Warming, New York, Viking, 2007 (1997).

HARLEY, Brian, "Maps, Knowledge and Power," in Denis Cosgrove and Stephen Daniels, eds., The Iconography of Landscape, Cambridge, Cambridge University Press, 1988, 277-312. 
HAWTHORNE, Christopher, “Architects Change Their View of the Lowly Roof," Los Angeles Times, November 6, 2006, http://articles.latimes.com/2006/nov/06/entertainment/et-google6 HEFFERNAN, Mike, "The Politics of the Map in the Early Twentieth Century," Cartography and Geographic Information Science, 29 (2001): 207-26.

JACKSON, Mark and DELLA DORA, Veronica, “'Dreams So Big Only the Sea Can Hold Them': Manmade Islands as Cultural Icons, Travelling Visions, and Anxious Spaces," Environment and Planning A, 41 (2009): 2086-104.

JACOB, Christian, The Sovereign Map: Theoretical Approaches in Cartography throughout History, Chicago, University of Chicago Press, 2006.

JOHNSON, Ian, "Spatiality and the Social Web: Resituating Authoritative Content," in Michael Dear et al., eds., Geohumanities, London and New York, Routledge, 2011, 267-76.

KINGSBURY, Paul and JONES, John Paul III, "Walter Benjamin's Dionysian Adventures on Google Earth," Geoforum 40 (2009): 502-13.

LUKERMANN, Fred, "The Concept of Location in Classical Geography," Annals of the Association of American Geographers 51 (1961): 194-210.

MANGANI, Giorgio, Cartografia morale: geografia, persuasione, identità, Modena, Cosimo Panini, 2006. MONMONIER, Mark, “Cartography: The Multidisciplinary Pluralism of Cartographic Art, Geospatial Technology, and Empirical Scholarship," Progress in Human Geography 31 (2007): 371-79. PARKS, Lisa, “Digging into Google Earth: An Analysis of 'Crisis in Darfur," Geoforum 40 (2009): $535-45$.

PTOLEMY, Claudius, “Geographikē Yphēgēsis” (excerpts). In A Sourcebook in Greek Science, I. E. Drabkin and M. R. Cohen, eds., Cambridge, MA, Harvard University Press, 162-81.

RAYWARD, Boyd, ed., European Modernism and the Information Society, Aldershot, Ashgate, 2008.

RECLUS, Élisée, Geographie Universelle, vol. 1, Chapter One, 1875. Available at: http:// www.gutenberg.org/files/28370/28370-0.txt, accessed on 15 Jan. 2012.

RICHARDSON, Miles, "The Gift of Presence: The Act of Leaving Artefacts at Shrines, Memorials, and Other Tragedies," in Paul Adams et al., eds., Textures of Place: Exploring Humanist Geographies, Minneapolis, University of Minnesota Press, 2001, 257-72.

SCAFI, Alessandro, Mapping Paradise: A History of Heaven on Earth, London, British Library, 2006.

SCHMIDT, Marcella, ed., Cos'è il mondo? È un globo di cartone: insegnare geografia fra Otto e Novecento, Milano, Unicopli, 2010.

SONTAG, Susan, On Photography, New York, Picador, 2001 (1977).

THRIFT, Nigel, "Beyond Mediation: Three New Material Registers and Their Consequences," in Daniel Miller, ed., Materiality, Durham, NC, Duke University Press, 2005, 231-55.

TUAN, Yi-Fu, Who Am I? An Autobiography of Emotion, Mind and Spirit, Madison, University of Wisconsin Press, 1999.

VAN PASSEN, Christian, The Classical Tradition of Geography, Groningen, J.B. Wolters, 1957.

WOOD, Denis, The Power of Maps, New York and London, The Guilford Press, 1992.

YATES, Francis, The Art of Memory, Chicago, Chicago University Press, 1966.

Websites 
Appalachian Voices: http://earth.google.com/outreach/cs_app_voices.html, accessed on Jan. 1, 2012.

GE downloaded more than one billion times: http://googleblog.blogspot.com/2011/10/googleearth-downloaded-more-than-one.html, accessed on Jan. 1, 2012.

GE Philosophy: http://googleearthphilosophy.blogspot.com/, accessed on Jan. 1, 2012.

Rooftop paintings visible from satellite: http://inhabitat.com/stunning-rooftop-paintings-thatcan-be-seen-from-satellites/, accessed on Jan. 1, 2012.

Cartography for all: http://oneworldmanystories.com/1_billion.html, accessed on Jan. 1, 2012.

\section{NOTES}

1. See Gore, 2007(1997).

2. Kropotkin proposed an international school network as an antidote to nationalist hatred. Anticipating Gore's vision, Kropotkin's project was meant to put Russian and English pupils in correspondence through letters and exchanges of small collectibles from their respective countries, including geological samples and local artefacts, thus casting the basis for peaceful dialogue between future generations (156). Similar ideas are echoed in the writing of Zonia Barber (1862-1856).

3. Echoing British claims that the era of geographical discoveries had come to a close, Penck insisted that "the end of the nineteenth century marked the perfect time to begin such an ambitious, collaborative project" (Heffernan, 2001, 209).

4. "The site has raised concern among some critics over privacy and intrusion, criticisms that have been voiced since the early days of aerial. In response, high-res images are deliberately at least $3 \mathrm{yr}$ old, and although individual cars can be distinguished, licence plates remain unreadable" (Cosgrove and Fox, 2010, 77).

5. As the artist comments: "This project uses materials from the waste stream (discarded house paint) to mark a physical presence in digital space. My work is generally concerned with human perception of current conditions; the Paintings for Satellites are specifically concerned with the effects of the digital on our physical bodies" (http://www.flickr.com/photos/mollydilworth/ sets/72157623364560566/).

\section{AUTEUR}

\section{VERONICA DELLA DORA}

School of Geographical Sciences, University of Bristol 